\title{
THE HUMANITARIAN IMPERATIVE: COMPROMISES AND PROSPECTS IN PROTRACTED CONFLICTS ${ }^{*}$
}

DOI: 10.20542/2307-1494-2018-1-54-66

\begin{abstract}
At present, the protracted nature of many conflicts raises profound dilemmas and issues for the humanitarian sector. Afghanistan, South Sudan, Libya, Syria, and Yemen in particular, resonate as long-term conflicts with long-term international presence, complicated by fragmentation and complex political influences, and without projected resolutions - all at the immense cost of the civilian population. Humanitarian response, built upon the fundamental, widely known and accepted international norms and rules, has significant and consequential operational limits and challenges to cope with. This article exposes some of the issues of international humanitarian deployments, access, the practical application of humanitarian principles, and the instrumentalization of aid. It also emphasizes the importance, even at the active conflict phase, of considering the long-term implications of aid by continuing to engage and invest in local community relationships and infrastructures to enable sustainable and impactful outcomes.
\end{abstract}

Keywords armed conflict, humanitarian aid, International Humanitarian Law (IHL), local actors, authoritarian regimes, humanitarian dilemmas, sustainable humanitarian action

Название Гуманитарный императив: компромиссы и перспективы в затяжных статьи конфликтах

Аннотация Затяжной характер многих современных конфрликтов ставит перед гуманитарным сектором ряд фундаментальных вызовов и дилемм. Афрганистан, Южный Судан, Ливия, Сирия и особенно Йемен - это продолжительные конфликты, которые служат ареной длительного международного присутствия, осложнены высокой степенью фррагментации насилия и запутанным клубком политических фракторов и не имеют решения в обозримой перспективе, что ведет к особо тяжелым последствиям для гражданского населения. В этих условиях гуманитарное реагирование, базирующееся на ффундаментальных, широко известных и общепринятых международных нормах и правилах, сталкивается с серьезными препятствиями и ограничениями на оперативном уровне. В статье рассматриваются некоторые аспекты современных международных гуманитарных операций, проблемы гуманитарного доступа, применения гуманитарных принципов на практике, а также инструментализации гуманитарной помощи, т. е. ее использования в иных целях. Подчеркивается важность учета, в т.ч. на активной стадии конфликта, долгосрочных последствий оказания гуманитарной помощи путем формирования и инвестирования в общественные структуры и инфраструктуру на местах в целях придания устойчивости и реального веса процессам постконфрликтного восстановления.

Emmanuel Tronc is a Senior Research Analyst at the Advanced Training Program on Humanitarian Action (ATHA) at the Harvard University Humanitarian Initiative.

\footnotetext{
* The author would like to thank Anaïde Nahikian (Harvard Humanitarian Initiative), Peter Harling (Synaps) and Simar Singh (Conflict Dynamics International).
} 
Ключевые слова вооруженный конфрликт, гуманитарная помощь, международное гуманитарное право, локальные акторы, сильные государства, гуманитарные дилеммы, устойчивая гуманитарная деятельность

Titre d'article L'impératif humanitaire: accommodements et perspectives aux conflits armés

Annotation II réside à l'heure actuelle de nombreux conflits dont le traitement apporté suscite de profondes interrogations. En effet, l'Afghanistan, le Sud Soudan, la Libye, la Syrie, ou encore le Yémen entre autres contextes de crise résonnent surtout comme des conflits qui perdurent, sans solutions rapides et au prix d'immenses souffrances pour les populations civiles. Mais aussi comme des conflits où les réponses humanitaires, si elles sont construites sur des bases et des règles connues et acceptées largement par tous, connaissent de réelles limites opérationnelles et de multiples défis auxquelles elles peinent à faire face. Cet article expose certains enjeux de la présence internationale, de l'accès humanitaire, de la mise en pratique des principes humanitaires et de l'instrumentalisation de l'aide. II insiste aussi sur l'importance, et ce malgré la situation de conflit, de mieux et plus soutenir les initiatives locales et communautaires afin d'avoir de meilleurs résultats sur le long terme.

Mots-clés conflit armé, aide humanitaire, droit humanitaire international (DHI), acteurs locaux, régimes autoritaires, dilemmes humanitaires, action humanitaire durable

\section{Introduction}

While the overall number of conflict, violent, or insecure environments has been declining globally over recent decades, ${ }^{1}$ there remain more than 30 contexts of protracted conflict around the world. They include Syria, Iraq, Yemen, Libya, Afghanistan, Somalia, South Sudan, as well as those less reported, such as the Democratic Republic of the Congo, Central African Republic, Northern Nigeria, and east Ukraine. ${ }^{2}$ These contexts represent significant challenges for humanitarian action in light of their complexity, endurance, and fragmentation. In response to these crises, practitioners are confronted with systems of intrastate, societal violence and rising levels of social dislocation, asymmetric deployment of forces, and engagement of multiple and diverse actors, including those marginalized from the prevailing political and normative system.

The "formal" aid system, organized around the United Nations, the Red Cross / Red Crescent Movement, and the network of non-governmental organizations (NGOs) contracted as the implementing partners of larger agencies, has tried to adequately adapt in response to these challenges. The sector has undergone constant growth and expansion during the past decades, convincing donors to commit increasing amount of funding on a longer term to these large-scale and sustained humanitarian crises. ${ }^{3}$ With donors supporting operations beyond the "acute" phase of intervention, many humanitarian organizations are confronted with the challenge of rendering humanitarian assistance more "sustainable". This leads to an extension of the humanitarian enterprise into a more lasting presence, or even development programming.

Beyond the UN system, there has been a surge in the number and size of humanitarian actors operating in these contexts, including large international NGOs (INGOs), but also local and regional organizations, faith-based agencies, and a growing number of interventions from the private sector. As the number and diversity of these actors has increased, ${ }^{4}$ so has the capacity of organizations to mobilize resources, intervene in acute settings, and target beneficiaries, whether directly or indirectly through implementing partners. 
In parallel, the aid system has pursued its course of professionalization via several management and accountability mechanisms: increase of personnel at the headquarters and at capital levels, and investment in the creation of new positions to analyze, prepare, evaluate, monitor, and debrief operations and performance. This evolution is meant to develop not only individual professional skills, but also the operational capacity of large humanitarian organizations to assess, negotiate, access, and deploy in complex environments.

While the humanitarian system, as a whole, rests on a set of normative rules and humanitarian principles, the changing dynamics of conflict have rendered the implementation and operationalization of these principles increasingly challenging, leaving a significant proportion of acute and emerging needs unaddressed. Moreover, the impetus to preserve financial support and to show success stories and humanitarian commitment spurred further competition among humanitarian organizations for funding, relevance, presence, and proximity. Competition reduces transparency and critical debates on operational limitations, compromises efforts to negotiate and maintain access to affected populations, and stifles reflection on the obstacles and failures of efficient delivery of assistance and protection to the most affected. This lack of exchange amongst humanitarians means that professional humanitarian community as a whole is not learning sufficiently from the experiences of difficult decisions made in response to important operational and policy dilemmas. This is particularly evident in conflict settings where the most vulnerable are first and foremost civilian populations. ${ }^{5}$

As seen in today's prolonged conflicts, recurrent dysfunction in the aid system lies in its absence of meaningful introspection on its sustained presence, including its financial aspects, how it balances its pragmatic priorities with principled ambitions, and the long-term vulnerabilities and dependencies that operational compromises may create for the most affected populations. While this article does not try to list them all, it identifies a few that are central to professional humanitarian debates today.

\section{Guiding international normative framework: the role of IHL and human rights}

The international normative framework (INF) ${ }^{6}$ specifies the rights, duties, and obligations of parties to an armed conflict - States and Non-State Armed Groups (NSAG), third States that are not parties to the conflict, humanitarian actors, and others concerning humanitarian access. Knowing and understanding the INF are critical to strategic planning, negotiating humanitarian access, and navigating operational challenges with key stakeholders in a conflict scenario. ${ }^{7}$

Unfortunately, in most insecure environments today, INF is not referred to on a regular basis to raise an issue, advocate for a change, address or denunciate a situation, or negotiate access is not done regularly. Humanitarians are increasingly reluctant to refer to the INF and invoke international humanitarian or human rights principles as such when engaging in dialogue with the parties and negotiating their field presence, security impediments, and access to affected populations.

In practice, humanitarians are also reticent to link their interventions to human rights principles, apart from the window of protection activities that may prove politically and operationally challenging to implement in acute humanitarian contexts. Indeed, despite awareness of severe protection needs in Yemen, Syria, Central African Republic, and South Sudan, humanitarians may be willing to compromise and tolerate insufficient protection standards as they privilege assistance. This may create an artificial separation between assistance and protection activities, which, according to humanitarian principles, should be unified.

Many humanitarian actors, INGOs, and local actors alike have a limited understanding of INF and question the utility of IHL, given its increasing distance from the practical realities 
of the field, in particular the problem of negotiating better access in conflict. ${ }^{8}$ Others, having witnessed decades of intentional failure to respect IHL (and IHRL) by state parties, refer to the normative erosion of the law, rather than ignorance of the norms themselves, and express general scepticism about the influence of IHL. ${ }^{9}$

Humanitarian actors are also increasingly aware of their role in the international community organized around a set of rules and norms. That role may be incompatible with prevailing legal and political structures in a given context. This aggravates the issue of whether humanitarians can be perceived as a moral face, claiming its constant legitimacy to act, intervene, and talk in the names of others, with strong ideas on what best for affected populations. These introspections provoke fundamental debates inside the humanitarian community on the relevance of international norms. Central to this debate are the following questions:

- How to draw and maintain attention to the prevention of human rights violations, ensuring that human rights issues are addressed before and during conflict?

- How to increase alignment between human rights and international humanitarian legal norms to enhance protection of civilians, vulnerable populations, and resolve to denounce failures to respect applicable law?

- How to create and enforce more robust accountability for violations of international humanitarian law?

\section{Dilemmas of the operationalization of humanitarian norms}

As presented in different manuals, and in particular the Practitioner Manual on Humanitarian Access in Situations of Armed Conflict, ${ }^{10}$ humanitarian principles guide in identifying priorities when needs are numerous and resources are limited, giving priority to the most urgent needs. They also guide the delivery of aid without differentiating between people or communities on the basis of nationality, race, gender, religious belief, class, or political opinions. Upholding the principles of humanity and impartiality may, in practice and where possible, involve consulting with people in need in order to understand and meet their needs effectively. It may also require closely monitoring the quality and means of delivering assistance, as well as taking measures to avoid resource diversion. Humanitarians must also avoid taking, or being perceived to take, sides in a conflict situation, and their actions must be independent from the political, economic, military, or objectives of other actors. In situations of armed conflict, these principles become a core part of good security management, protecting both humanitarians and the people they are serving.

By not engaging all relevant actors, humanitarians may be perceived as taking sides to a conflict, potentially missing opportunities to negotiate access to certain populations, and compromising their ability to provide assistance impartially. As an example, the act of negotiating with a NSAG - regardless of its designation or legal status - does not in and of itself compromise perceptions of neutrality.

In fact, acting in line with humanitarian principles demands that humanitarians engage all relevant actors equally for the purposes of gaining access to people in need. While the doctrine of principled humanitarian action continues to guide humanitarian interventions, the confluence of operational realities such as deliberate and recurrent violations of IHL, limited access, politicization of assistance, and insecurity of staff in protracted conflicts such as Syria, Yemen, Iraq, South Sudan, Libya, and Central African Republic significantly constrain and limit international interventions. ${ }^{11}$

\section{(a) Invoking humanitarian law and principles in negotiating access}

Invoking humanitarian law and principles in negotiating access is a dilemma at the heart of most other dilemmas presented below. While humanitarian principles should be 
used as a guiding standard, in conflict settings, very few humanitarian actors actually "promote" and implement a strictly principled approach. ${ }^{12}$ Despite solid evidence that the principled approach tends to produce more positive outcomes in the long run, ${ }^{13}$ humanitarian actors, driven by emergency and short-term pragmatism, often limit the use of principles that can be difficult to explain or demonstrate - particularly neutrality and impartiality - which in practice may lead to hierarchizing and compromising some principles for the sake of others. ${ }^{14}$

A majority of local NGOs may also have difficulty integrating practical application of humanitarian principles and leveraging them during dialogue and negotiations with authorities or armed groups. In many non-Western contexts, there is a perception that these principles form a "Western posture" which is neither relevant, nor universal. In highly politicized and divisive contexts such as Syria, which has seen restricted operations since 2011 and lack of impactful humanitarian assistance to besieged areas, how can agencies demonstrate their independence, humanity, neutrality, and impartiality ${ }^{15}$

Discussions of the practical use of humanitarian principles in conflict remain confined to debates at key humanitarian hubs and summits, ${ }^{16}$ generating hollow statements in the name of their preservation and support. In contrast, in the field in various conflict environments, such as in Northern Nigeria, the general trend is to be relatively discreet about defending and espousing humanitarian principles, focusing instead on building confidence, gaining trust, being patient, privileging dialogue, and understanding the needs on the ground.

Even when this approach to negotiating access does not bring systematic and visible outcomes, it definitely impacts operational actions in conflict and the way beneficiaries and local populations perceive humanitarian actors. In such contexts, it remains fundamentally important to, at the very least, continue to assert the humanitarian principles - otherwise, not doing so may suggest that everything is negotiable. Furthermore, it is important to understand which principles are more or less valued in dialogue and negotiations with relevant interlocutors. If a degree of pragmatism at the operational level is to be accepted and understood, the humanitarian community should not discourage debate on how principles may ultimately limit operational access. As an aspirational goal, humanitarian principles are aligned with realities on the ground. In practice, however, there is a growing gap between paying lip service to the principles and the need to compromise on them to some degree.

\section{Strong states and humanitarian access}

Humanitarian aid in conflict is provided within a political context, often at the intersection of various political agendas. Many governments try to exercise greater control over humanitarian programs at the field, restrict aid to certain regions, in particular the ones in the hands of non-state actors of armed opposition or other NSAGs, create deliberate obstructions, or establish restrictions on population movements. This is particularly the case when central authorities are described as "strong" vis à vis the international community and the humanitarian sector. ${ }^{17}$

The current conflicts that occupy the media and international attention on a daily basis do not produce many "good stories" about the level of access, and the quality and effectiveness of humanitarian deployment. In Syria, the main providers of aid organized through the United Nations Country Team (UNCT), acting from Damascus and with strict procedures imposed by the regime authorities, acknowledge their constraints to deliver humanitarian assistance across the country where several million people remain in need of humanitarian assistance on a daily basis. ${ }^{18}$ If the government grants authorizations to run humanitarian and medical programs, detailed information on these activities, the field foot print, concrete protection outcomes for affected populations, and the challenges these programs confront is not really or readily available. 
In Yemen, the UN officials publicly mentioned the figures of 7 million people in dire need of humanitarian assistance. Still, humanitarian programs are limited, and several programs were cancelled, due to insecurity and limited success in negotiating access. In Nigeria, as of 2018, humanitarian actors mention the approximate figure of 930 thousand people not accessible today, in particular in Borno State and at its borders.

Similar realities - populations that are either cut from aid, or under-assisted - are widespread in places such as South Sudan, part of Somalia, the region of Donbass in Ukraine, the Rakhine State in Myanmar, several provinces in Afghanistan, half of Central African Republic and Mali, two thirds of Libya, and numerous pockets in many other contexts where civilian populations deserve rapid and comprehensive assistance but humanitarians are nearly absent. Instead, they subcontract their interventions with basic management grips, promote alternatives that weaken the humanitarian approach and principles (through cash distribution and resilience programs, for example), and limit the awareness of the situation to avoid major criticisms, underestimating the impact of its inadequacies to respond and assist.

On the one hand, the aid community advocates the imperative to be devoted to beneficiaries first, at any cost, making important compromises on principles (in particular impartiality and neutrality), but de facto being instrumentalized by political actors. On the other hand, this instrumentalization will limit the access and credibility of humanitarian actors to run principled operations on the ground in the long run.

While developing relationships with states and non-state actors alter humanitarian sector's political considerations and notions of operational engagement, it is regrettable that humanitarians largely concede to specific conditions set by state authorities, even if they severely limit (for a certain time or indefinitely) humanitarian operational access in the field.

\section{(b) Speak out or stay quiet?}

The largest and most intense contemporary conflicts lead to frequent and widespread abuse of the laws of war, diminished protection of civilians, intimidation or even direct attacks on civilians ${ }^{19}$ and humanitarians' endeavors, their personnel, and facilities, ${ }^{20}$ and impose restrictions on humanitarian dialogue with all parties, particularly NSAGs. In many cases, limiting public advocacy or communication and denunciation of blockages, malfunctioning of aid, human rights or IHL violations can be humanitarian actors' deliberate strategy to maintain field presence and proximity in a conflict situation.

In most cases, limited presence and restricted deployment of humanitarians in the worst affected contexts does not stem from the international humanitarian sector's ignorance of the crises on the ground, but result from deliberated choices and priorities to accept important operational conditions and compromises. These pragmatic reflections in contexts such as the Caucasus, South Sudan, Myanmar, Nigeria, Syria, Yemen, among others, are meant to preserve assets, limit security risks, avoid confrontational negotiations that can be detrimental to the institution, restrict public denunciation of access obstructions, deliberate instrumentalization of aid, and violations of IHL by the belligerents.

How far should actors concede to a situation if it means hindered access to populations in need, limited capacity to assess and collect pertinent data on the current situation, diminished quality and efficiency of humanitarian aid, and erosion of the humanitarian character of assistance and protection activities?

Humanitarians active on the ground should be expected to speak out about these challenges, despite potential repercussions such as the "loss" of perceived neutrality or access. Perhaps they can speak out directly with the party concerned, but not in public. Other parties, especially states that respect and invest in the normative order, may also be in a better position to speak out and should do so. The question of who should speak out remains valid if it is considered in view of consequences for humanitarian access. 
Aid recipient states, particularly fragile and conflict-torn ones, are strongly opposed to any public communication from humanitarian actors that can illustrate their role and responsibilities vis à vis their own population and society, and brandish their sovereignty to limit the deployment of international actors that can witness the authorities' behavior towards the civilians. This represents a major challenge for humanitarian actors to analyze, take into account, build upon the capacities of states to respond, and limit substitution and support local infrastructure and mechanisms, in order to push them to take their own responsibility with respect to their populations. In some situations, pressure does not have to be leveraged publicly, but this opportunity should be available and encouraged. ${ }^{21}$

\section{(c) Reliance on implementing partners in a lack of operational access}

International humanitarian actors are confronted with important access and deployment limitations in conflict settings. These can be related to bureaucratic impediments, restrictions of the size and location of operations by the central authorities, limited acceptance by local communities and NSAGs, security issues (such as field exposure to diverse attacks) and the extent of internal willingness to mitigate these risks. The use of local staff and implementing agencies to manage programs in a remote manner has become increasingly common in many conflict settings (and, above all, in Somalia, Afghanistan, and Syria). ${ }^{22}$

There is no doubt that using local actors brings various advantages for an international entity, including operational flexibility and agility, ongoing field presence and rapid mobilization when conflict escalates, direct access to local authorities, credibility, and better understanding by local communities of the goals and nature of humanitarian presence. That said, this method also implies that local staff will be exposed to significant risks, pressures, and scrutiny on how funds are used, how staff is recruited, and how operational decisions and priorities are made. As explained by a recent survey, local organizations have to navigate a variety of challenges and dilemmas in their work, making choices that compromise adherence to the humanitarian principles in order to adequately maintain field presence. ${ }^{23}$ Generally speaking, international actors usually choose this option as a last resort, to facilitate presence, sometimes with acknowledgement of limited quality and effectiveness of local actors' programming. The trust and confidence in local capacities to deliver remain to be further exposed.

A direct consequence is that the support for operations remains controlled by larger international agencies and narrowly distributed, despite commitments to reinforce local and national capacities and the recognition that national entities are often the primary responders in crises. Local NGOs only receive a very small proportion of international humanitarian assistance directly, prompting calls for greater "localization". ${ }^{24}$ Only $2 \%$ of international humanitarian assistance in 2016 went directly to local and national responders and just $0.3 \%$ directly to local non-governmental organizations. ${ }^{25}$

Also, the way local actors tailor projects, with a multiplicity of small financial requests, condemns them to remain marginal to the main financial providers that privilege large scale financial proposals, ${ }^{26}$ mainly to limit the risks and workload of monitoring each initiative. This reality also affects middle-size international NGOs, compelling them to develop consortiums in order to respond to large appeals. In the process, some local NGOs can join such consortiums but the majority of actors remain international agencies. Local actors remain small, with simple programs and limited perspectives. They are fragile, can be weakened rapidly by the conflict actors and by the international organization, and rely on multiple support channels that make them very dependent and limit their visibility and their opportunities to present more concretely their unique added value. If the voice and face of local actors can be intentionally low-profile, in order to protect themselves from various threats and risks on the ground, in the aid system, their presence and approaches should be definitely more visible and supported. 


\title{
(d) Constraints and instrumentalization of humanitarian aid
}

\author{
Integrated missions and civilian-military engagement
}

In Afghanistan, since the deployment of Provincial Reconstruction Teams (PRTs) in $2002,{ }^{27}$ there has been increased interdependence and convergence between the humanitarian community, on the one hand, and military actors, on the other, who supported their own strategic goals through direct delivery, collaboration with civil society, or protection of humanitarian assets. Moreover, states and their militaries have used humanitarian purposes as a means to justify military intervention.

If political actors see the importance of including a humanitarian "dimension" to their discourse and agenda, it draws the humanitarian sector into a broader web and agenda of conflict and stabilization that includes security issues and military intervention, mediation and diplomacy, peacebuilding, and long-term development. This situation de facto politicizes what should be neutral and independent humanitarian assistance, erodes its neutrality, and can create the perception by local populations of a partial approach.

While highly criticized, the concept of integrated missions has been validated and practiced in several UN interventions over the past decades. However, from the perspective of humanitarian action on the ground, it has been observed that with integration, humanitarian workers face challenges and risks in their operations that they would not otherwise confront in "purely humanitarian" missions. The integration of three operational communities - the humanitarian, security, and political sectors - each with distinct principles and methodologies, may lead to poorly understood mandates, professional standards, and inconsistently implemented policies. Integration with agencies that do not share and prioritize humanitarian principles in their operations hampers humanitarian access to those in need and may expose personnel to additional safety risks.

At a country level, aid may be more highly scrutinized and controlled to validate security threats and concerns as conditions for a deployment of humanitarian assistance. Preventing political actors from using humanitarian terminology and from using humanitarian imperatives as a pretext for military intervention is a growing challenge that has to be closely followed and addressed from one context to another.

\section{Financial competition and donor predictability}

International assistance is channeled through a number of different institutions and mechanisms that have the objective to support and facilitate the efficiency and effectiveness of humanitarian response. Important commitments, reiterated on a regular basis, engage donors and humanitarian agencies to improve the way funding is provided and delivered. ${ }^{28}$ However, there are several problems to be addressed, particularly in connection to the independence of actors and the impartiality of donors.

First, the number of large recipients of international funds is very limited. The main agencies that receive institutional funding are those of the UN system ( $46 \%$ of the total in 2016), and those are mainly the top agencies (such as the UNHCR, WFP, or UNICEF), followed by the ICRC/Federation (18\% in 2016). ${ }^{29}$ These agencies then redistribute financial support at their discretion to hundreds of international NGO partners they have, who then redistribute to local implementing agencies, creating a "trickle down" and indirect financing model.

Yet, there remains weak trust and confidence in the pertinence of these proposals, in particular those developed by the UN appeals on a yearly basis, as illustrated by the fact that in 2016 around $40 \%$ of UN appeals were not fulfilled (funding provided in response to these appeals increased in 2016 to 12.4 billion USD, but still left a gap of 8.2 billion USD $-40 \%$ of 
the total requested). ${ }^{30}$ Not surprisingly, "small" humanitarian actors, and in particular local ones, cannot directly access these funding opportunities, despite bearing a significant share of daily operations.

Second, much of international humanitarian assistance continues to come from a very small number of donors. Five government donors together contributed almost $65 \%$ of total funding in 2016, ${ }^{31}$ and one donor (the United States) provided more than $31 \%$. In the same period of time, while combined contributions from European donors rose by $25 \%$, those from donors in the Middle East and North Africa (MENA) countries fell by $24 \%$. From one year to another, there are some government donors that increase their contributions, particularly considering the current situation in the Middle East. One exception is the Yemen crisis, to which donors in the Middle East region provided $50 \%$ of total funding in $2016 .{ }^{32}$

It is alarming to see that few crises monopolize the majority of funding. Humanitarian funding was concentrated on a few large emergencies in 2016. That same year, five contexts (Syria, Iraq, Yemen, Lebanon, and South Sudan) received most international humanitarian assistance - more than half (54\%) of all crisis-specific funding. ${ }^{33}$

The potential of private sources of funding has continued to draw attention as a future approach to humanitarian financing. But the reality is that private donors, individuals, trusts, foundations, and corporations choose an opportunistic approach, based on specific themes or projects (health, education etc.) over support to institutions and global programs. They are also far more vigilant on how the funding is used, how efficient and pertinent the activities are, and how sustainable is the project in the long run. As, for instance, demonstrated by the Syria conflict, a lot of funding was mobilized through Islamic social financing, e. g., in reaction to specific tragedies (cities bombed, besieged areas), where population had limited access to the formal aid system. The "leveraging" potential of private sector and individuals is difficult to evaluate, but represents a real opportunity to assist more affected populations and support small entities that can deliver tailored and efficient interventions. ${ }^{34}$

\section{Conclusions: prospects for sustainable humanitarian action in protracted conflicts}

For critical consideration of challenges, constraints, and ongoing debates on humanitarian professional standards and mandates with regards to operational compromises and new methods of work in rapidly changing conflict environments, it is essential to better identify the limits of humanitarian programs in conflicts and protracted crises, with particular attention to the quality and long-term implications of humanitarian action.

Despite well-intended commitment to protection of civilians, enhanced professionalization of humanitarian activity, and increasing resources and capacity over the past 20 years, the international "aid system" has made limited headway in reforming itself sufficiently to rebalance the needs, constraints, and power relationships that operating in highly complex, fragmented, and political environments requires. Monitoring the system's efficiency remains confined to the surface level and does not specify, assess and address the responsibilities of actors. As the case of Syria illustrates, the aid sector continually confronts its deep and inherent malfunctioning as a collective mea culpa.

One alternative venue, in light of these chronic challenges and the imperative to better assist affected populations, is to recommit engagement in locally-driven operational approaches, tapering off some large-scale international interventions in favor of longer-term local initiatives, not only from the humanitarian perspective, but also in terms of development of local civil society as a whole. 


\section{(a) Consideration of economic and social vulnerabilities in humanitarian programming}

Contemporary conflict settings are often and increasingly concentrated in fragile states, where people are already facing major vulnerabilities in terms of poverty and underdevelopment. ${ }^{35}$ It is estimated that over $85 \%$ of those living in extreme poverty (at least 650 million people) live in fragile and insecure environments. Poverty data is still missing for most countries that became objects of the largest humanitarian responses. For nine out of ten conflict countries that receive the largest amounts of international humanitarian assistance over the last decade, there is no reliable up-to-date poverty data. ${ }^{36}$ This includes all five largest aid recipients in 2015 - Syria, Yemen, Jordan, South Sudan, and Iraq. In Yemen, where the crisis has left $69 \%$ of the population in humanitarian need, according to the UN OCHA, poverty might have doubled to $62 \%$ from 2015 to $2016 .^{37}$ While national averages may provide a clue about overall poverty and risk, these levels often differ greatly within countries and are compounded by other factors such as insecurity, population movement, and climate-induced scarcity. ${ }^{38}$

In the 2010s, the number of people forced into displacement by conflict or violence has also increased drastically to reach more than 65 million in 2016, with the vast majority of them internally displaced, representing a constant increase over more than five years. External and emerging factors (climate changes, drought, scarcity of food and resources, and insecurity) that exacerbate existing vulnerabilities have major consequences on affected populations and must be integrated into humanitarian programs beyond acute emergency phases. Improved collection of data and analysis of vulnerabilities are a sine qua non for new commitments to longer-term and more impactful interventions.

\section{(b) Sustainable actions and reducing aid dependency}

There are many important long-term socio-economic implications of conflicts and humanitarian crises that humanitarians are not in a position to manage for "mandate" reasons. Some of these implications, however, are direct consequences of limited access and the ways in which humanitarian actors prioritize and build their operations.

Deploying aid and humanitarian programs either during an acute emergency phase or in a situation of protracted conflict necessitates strategic prioritization, negotiation, and decisions that can limit the scale or sustainability of an operation. That said, based on solid operational experience, humanitarian actors are aware of the implications of supporting local systems and infrastructures, including local staff training. Without a long-standing commitment by the authorities, these will not remain autonomous and sustainable after the international humanitarian organization's departure.

Taking a long view with the necessary operational commitments to follow, sharing good practices during the critical phases, limiting discouragement for long-term support, in particular from the international community, and contributing to bridging actors across the humanitarian and development sectors, should not be just part of an optional policy discussion. These considerations and imperatives should strategically guide the design and implementation of humanitarian operations and relationships with local communities and authorities. Even in protracted insecure environments, where there is an aid "fatigue" and de facto operational limitations, bridges between emergency and development interventions should be better identified and supported before ending a program. Humanitarian needs are human needs and endure long after humanitarian interventions.

Today, the existence and impact of local initiatives by civil society actors, humanitarian or development based, and by local communities in affected conflict settings are far from being adequately supported, documented, shared, and highlighted by key international players that attract the majority of media and stakeholders' attention. This is particularly the 
case in such conflict settings as Syria, Iraq, Yemen, or Libya where local actors struggle to maintain minimum training (for example, in medical education and negotiation skills), technical, and financial support to implement programs and assist their communities. ${ }^{39}$ Support to local actors across contexts and conflicts remains marginal, if not deliberately deprioritized. The continuing prevalence on focus on "international aid" in protracted crises at the expense of attention to and role of the local actors runs counter to humanitarian mission to ensure the protection and autonomy of populations and support local infrastructure in ensuring sustainable peace.

A committed shift toward greater emphasis on local actors will not only inspire new kinds of engagement during humanitarian operations, but will contribute to breaking the cycle of aid dependency, reinforcing trust in local governance mechanisms, and putting the responsibilities of actors for their future back in their own hands. ${ }^{40}$

\section{ENDNOTES}

${ }^{1}$ Global Conflict Tracker 2017. Council on Foreign Relations (CFR) Centre for Preventive Action [Washington D.C.]. URL: https://www.cfr.org/interactives/global-conflict-tracker\#!/global-conflicttracker.

${ }^{2}$ The Future of Aid: INGOs in 2030. Inter-Agency Regional Analysts Network (IARAN) report. - Paris, August 2017. URL: http://futureofaid.iaran.org/The_Future_Of_Aid_INGOs_In_2030.pdf.

${ }^{3}$ It represents over 28 bln USD in 2017, as compared to 16 bln USD in 2012 and approximately 6 bln USD in 2004, according to various reports from Development initiatives (DI), OECD and UNOCHA (FTS and CERF).

${ }^{4}$ In 2017, the United Nations offered consultative status to more than 3900 NGOs with roughly onethird of these located in the United States.

${ }^{5}$ According to UN OCHA (URL: https://www.unocha.org), for three countries (Yemen, Syria, and Iraq), this represents in 2017 over $45 \mathrm{mln}$ people in immediate need of international humanitarian assistance.

${ }^{6}$ Humanitarian Access in Situations of Armed Conflict: Handbook on the International Normative Framework Version 2. - Bern: Federal Department of Foreign Affairs, December 2014. URL: http://www.cdint.org/documents/Humanitarian_Access_Handbook-v2.pdf.

${ }^{7}$ General International Law (GIL) - law between nations, distinct from domestic law. International Human Rights Law (IHRL) - law that applies during peace time and with certain exceptions also during war time. It establishes a system of individual rights and freedoms. Primary duty bearers are states. International Humanitarian Law (IHL) - law that applies during war time. There are no exceptions from IHL, unlike IHRL. Primary duty bearers are the conflict parties. International Criminal Law (ICL) is a body of law meant to address a specific set of crimes that are considered so egregious as to be of international concern: crimes against humanity, war crimes, genocide.

${ }^{8}$ Grace R., Wilkinson S. Role of Laws and Norms in Humanitarian Negotiations, Advanced Training Program on Humanitarian Action. - Cambridge (Mass.): Harvard Humanitarian Initiative, September 2016.

9 "United against inhumanity. We, concerned citizens of every part of the world, say "Stop the slaughter! Protect civilians!". Proposal for an international campaign of individuals, March 2018 // Alternatives humanitaires / Humanitarian Alternatives. March 2018. URL: http//alternativeshumanitaires.org.

${ }^{10}$ Humanitarian Access in Situations of Armed Conflict. Practitioners' Manual. V. 2. - Bern: Federal Department of Foreign Affairs, December 2014.

URL: http://cdint.org/documents/CDI_Access_Manual_Web_Dec5.pdf. 
${ }^{11}$ Svoboda E. Strengthening Access and Proximity to Serve the Needs of the People in Conflict. Humanitarian Policy Group (HPG) Report. - London: ODI, August 2015.

URL: https://www.odi.org/sites/odi.org.uk/files/odi-assets/publications-opinion-files/9737.pdf.

12 ICRC and "Médecins sans frontiers" (MSF) are recognized by the aid community as the main organizations that currently implement a humanitarian principled approach.

13 Haver K., Carter W. What it Takes: Principled Pragmatism to Enable Access and Quality Humanitarian Aid in Insecure Environments. Secure Access in Volatile Environments (SAVE) Report. November 2016. URL: https://www.alnap.org/system/files/content/resource/files/main/save-2016principled-pragmatism-to-enable-access-and-quality-humanitarian-aid-in-insecure-environments. pdf.

${ }^{14}$ Negotiating Humanitarian Access: Guidance for Humanitarian Negotiators. Conflict Dynamics International (CDI) Access Brief no. 2. - Cambridge (Mass.): CDI, July 2017.

URL: http://www.cdint.org/documents/cdi_negotiation_brief_v1.10_english.pdf.

${ }^{15}$ Delattre F., Atlani-Duault L. Is Aleppo the grave of the United Nations? // The Lancet. V. 388. № 10059. November 2016. P. 2473.

${ }^{16}$ Most recent and emblematic summit was the United Nations World Humanitarian Summit (WHS) held in Istanbul, Turkey, on 23-24 May 2016. The summit was an initiative of the UN SecretaryGeneral Ban Ki-Moon and was organized by the United Nations Office for the Coordination of Humanitarian Affairs (UN OCHA).

17 Cunningham A.J. International Humanitarian NGOs and State Relations: Politics, Principles and Identity. - L.: Routledge, 2018.

${ }^{18}$ UN OCHA figures, November 2017. URL: https://www.unocha.org.

${ }^{19}$ Syria: Ceasefire violations reported in Eastern Ghouta // Al Jazeera. 27 January 2018.

${ }^{20}$ Kunduz Hospital Airstrike. Médecins Sans Frontières (MSF) web-site: Topics. October 2016. https://www.msf.org/en/topics/kunduz-hospital-airstrike.

${ }^{21}$ See the case of Synaps initiative that identifies and promotes local actions and solutions, and states' role and responsibilities. URL: http://www.synaps.network.

${ }^{22}$ As of February 2018, 152 NGOs were Humanitarian Response Plan (HRP) partners of OCHA in Syria. URL: https://www.unocha.org.

${ }^{23}$ Svoboda E., Barbelet V. and Mosel I. Holding the Keys: Humanitarian Access and Local Organizations. Humanitarian Policy Group (HPG) Report. - L.: Overseas Development Institute, 2018. URL: https://www.odi.org/sites/odi.org.uk/files/resource-documents/11981.pdf.

${ }^{24}$ Where is All the Money Going? The Humanitarian Economy. - Geneva: IRIN, September 2016.

URL: http://newirin.irinnews.org/the-humanitarian-economy.

${ }^{25}$ The Future of Aid: INGOs in 2030. Inter-Agency Regional Analysts Network (IARAN) report. August 2017. URL: http://futureofaid.iaran.org/The_Future_Of_Aid_INGOs_In_2030.pdf.

${ }^{26}$ Such as ECHO (European Commission for European Aid) or DFID (UK Department for International Development).

${ }^{27}$ See Provincial Reconstruction Teams (PRTs). NATO ISAF Topics. 8 November 2010. URL: https://www.nato.int/isaf/topics/prt/index.html.

${ }^{28}$ Grain Bargain Commitments. Inter-Agency Standing Committee (IASC). Last updated 20 February 2017. URL: https://interagencystandingcommittee.org/grand-bargain-hosted-iasc.

${ }^{29}$ The Future of Aid: INGOs in 2030. Op. cit.

${ }^{30}$ UN OCHA Financial Tracking Service (FTS). URL: https://www.unocha.org. 
${ }^{31}$ United States, Japan, United Kingdom, Canada and the European Union.

${ }^{32}$ Global Humanitarian Assistance Report 2017. - Bristol: Development Initiatives, 2017. URL: http://devinit.org/post/global-humanitarian-assistance-2017.

${ }^{33}$ Ibid.

${ }^{34}$ See, for instance, information about the Ruwwad initiative in the Middle East. URL: http://www.ruwwad.net.

${ }^{35}$ Addison T., Bach K., Shepherd A. and Wadugodapityia D. Fragile States, Conflict and Chronic Poverty. Chronic Poverty Research Centre Policy Brief no. 24. - L.: Overseas Development Institute, 2010. URL: http://www.chronicpoverty.org/uploads/publication_files/PB\%2024.pdf.

${ }^{36}$ Global Humanitarian Assistance Report 2017. Op. cit.

${ }^{37}$ Ibid.

${ }^{38}$ The Future of Aid: INGOs in 2030. Op. cit.

${ }^{39}$ Svoboda E. et al. Op. cit.

${ }^{40}$ Sarr F. Afrotopia. - Paris: Philippe Rey ed., 2016. 